\title{
The intertidal gastropods (Gastropoda: Mollusca) diversity and taxa distribution in Alas Purwo National Park, East Java, Indonesia
}

\author{
SUSINTOWATI ${ }^{1,2, \vartheta}$, NYOMAN PUNIAWATI ${ }^{3}$, ERNY POEDJIRAHAJOE ${ }^{4}$, NIKEN SATUTI NUR HANDAYANI $^{5}$, \\ SUWARNO HADISUSANTO ${ }^{1, \vee v}$ \\ ${ }^{1}$ Ecology and Conservation Laboratory, Faculty of Biology, Universitas Gadjah Mada. Jl. Teknika Selatan, Sleman 55281, Yogyakarta, Indonesia. \\ Tel.: +62-274-580839, Fax.: +62-274-6492355, ^^email: suwarnohs@ugm.ac.id \\ ${ }^{2}$ Department of Biology Education, Faculty of Teaching and Education Sciences, Universitas 17 Agustus 1945. Jl. Adi Sucipto 26, Banyuwangi 68416, \\ East Java, Indonesia. Tel./fax.: +62-333-411248. ^email: susintowati@yahoo.com \\ ${ }^{3}$ Animal Structure and Development Laboratory, Faculty of Biology, Universitas Gadjah Mada. J1. Teknika Selatan, Sleman 55281, Yogyakarta, \\ Indonesia \\ ${ }^{4}$ Departement of Forest Resource Conservation, Faculty of Forestry, Universitas Gadjah Mada. Bulaksumur, Sleman 55281, Yogyakarta, Indonesia \\ ${ }^{5}$ Genetics Laboratory, Faculty of Biology, Universitas Gadjah Mada. Jl. Teknika Selatan, Sleman 55281, Yogyakarta, Indonesia
}

Manuscript received: 17 March 2019. Revision accepted: 29 June 2019.

\begin{abstract}
Susintowati, Puniawati N, Poedjirahajoe, Handayani NSN, Hadisusanto S. 2019. The intertidal gastropods (Gastropoda: Mollusca) diversity and taxa distribution in Alas Purwo National Park, East Java, Indonesia. Biodiversitas 20: 2016-2027. Gastropods play an essential role in the ecosystem and can be used as bioindicators of environmental pollution. Understanding of their behavior, habitat, and distribution, and how these factors evolve, is crucial. This paper aimed to describe the diversity of the gastropod community and their spatial taxa distribution, based on the specimen frequency across all observed samples, in the diverse environment of Alas Purwo National Park (APNP), East Java, Indonesia. We studied eight beaches and two mangroves areas, and the study areas of the intertidal zone divided into upper, middle, and lower zones towards the sea. The purposive sampling was used to determine the locations and multi-plot quadrats for observations. The diversity of gastropods was elucidated by using the Shannon and Simpson indexes, while the Morisita index was applied for analyzing their spatial distribution pattern. However, the correspondence analysis and principal component analysis were performed using the software of PAST 3.22 for describing the diversity profile and individual rarefaction of gastropods together with environmental quality. There were three beach types: rocky, sandy, and muddy beaches were found in APNP. The highest diversity index (H') was found on Pancur beach: H' $=3.271, \mathrm{D}=0.947$ of 67 species. The spatial distribution pattern of gastropods species was weakly clumped to random, with Ip: $0.165-0.016$. Gastropods, both predators and scavengers, were distributed from the upper to lower zones. The distribution of gastropods in APNP is mostly in type B. These results expand our knowledge of gastropods diversity and distribution of Indonesia's beach and can contribute to the future environmental assessments of biodiversity of tropical intertidal zones worldwide.
\end{abstract}

Keywords: Alas Purwo National Park, distribution, diversity, gastropods, intertidal

\section{INTRODUCTION}

Intertidal zones provide a habitat for a plethora of marine organisms. We do understand that it's an extreme environment influenced by the tidal rhythm of the sea. Tidal levels (high and low) are the most important factor for marine life in intertidal zones because during the day, at the lowest tide, the high temperatures and sunlight radiation make the bottom very dry (Nybakken 1992). The fact of terrestrial disturbance is fatal to this zone. There are three main environmental gradients at the seashore: (i) the vertical gradient, (ii) the horizontal gradient, and (iii) the particle-size gradient. These gradients have a very specific environmental character. The increase of environmental stress is clearly shown across the vertical, intertidal gradient. Organisms are subjected to increased stress in this area. They need adapted structures, behavior, and functional capability to survive. The freshwater inflow into intertidal zones also increases physical pressure (Thatje and Brown 2009). Short (2012) purposed the beach system pattern and shore system, including many shapes of beaches and shores conduct to prosses called morphodynamic, but he did not focus on Gastropods distribution. Gastropod communities can be found in the deep sea (Braga-Henriques et al. 2011; Kantor et al. 2013; O’Dwyer et al. 2014; Hoffman et al. 2018).

Gastropods are the biggest class of Mollusca comprising $80 \%$ of this phylum (Strong et al. 2008). The distribution of organisms is influenced by physical factors, and ecological communities vary widely through time and space. Environmental variables are related to the taxonomic diversity of organisms (Koperski 2010; Scrosati et al. 2011; Marques et al. 2013). Spatial distribution patterns matter, as they are often used to support ecologically sustainable marine management information (Degraer et al. 2007; Schlacher et al. 2014). The distribution and diversity of gastropod communities in intertidal zones are influenced by environmental factors, such as temperature, DO, $\mathrm{pH}$, salinity, and $\mathrm{CO}_{2}$ (Parker et al. 2013; Wittmann and Pörtner 2013; Llovel and Terray 2016). The radical fluctuations and changes in the environment cause stress, and greatly affect intertidal organisms (Harley et al. 2009; Nguyen et al. 
2012; Abraham et al. 2013; Kroeker et al. 2013), including gastropods. They are also influenced by biological disturbance, such as introduced and invasive species (Raffo et al. 2014).

Biotic communities of the beach render essential services which are unavailable in other ecosystems and cannot be replaced (Marshall and Banks 2013). Intertidal gastropods play a significant role in marine life and keep the ecosystem in balance. Gastropods play different roles in the food chain, from herbivores, fungivores, carnivores, and omnivores, to scavengers, detrivores (Alongi 2009) and parasites (Hoeksema and Gittenberger 2008), and function as control of biodiversity in the intertidal zone. Many environmental assessments have studied gastropod communities as bioindicators of environmental pollution (Susintowati and Hadisusanto 2014; Van der Linden et al. 2016; Suratissa and Rathnayake 2017). It is therefore essential to understand their distribution, niche, and behavior, and how these factors change over time. According to Pfaff and Nel (2019), despite these extreme conditions in the intertidal zone, organisms adapted to various niches with high densities of sessile, or sedentary, organisms. Their case shows striking similarities to other places around the world. Benthic organisms in intertidal zones are influenced by and respond to coastline changes (Yang et al. 2018). This behavioral adaptation of intertidal gastropods constitutes a fundamental evolutionary advantage when facing a fluctuating environment (Chapperon and Seuront 2011).

Previous studies compared only a few beach gastropod communities, at one point in time, typically on a single beach type or in a single mangrove. Those previous studies are Mujiono (2009) studied mud whelks in Ujung Kulon National Park and Irma and Sofyatuddin (2012) studied gastropods in Aceh. Yolanda et al. (2016) conducted fieldwork on the Riau islands, while Rumahlatu and Leiwakabessy (2017) carried out research in Ambon. There is no complete marine gastropod record in APNP. This study aimed to describe the diversity of the gastropod community and the spatial taxa distribution pattern based on its frequency in APNP. APNP is a very diverse biotope of tropical beaches and shores. It has everything from rocky shores, sand beaches (black and creamy sand) and muddy shores, to seagrass beds, estuaries, and mangroves. We used this area because APNP is an undisturbed and natural conservation area. Vertical distribution littoral assemblages were studied earlier by Chappuis et al. (2014) covering the upper supralittoral to the upper infralittoral zones $(-1 \mathrm{~m})$. This research focuses on gastropod diversity and taxa distribution patterns from the upper to the lower intertidal zone. The results contribute to our understanding of Indonesia's beach habitats and could help future environmental assessments of intertidal zones in other tropical Pacific areas.

\section{MATERIALS AND METHODS}

\section{Study area}

We observed eight beaches and two mangroves in Alas Purwo National Park (APNP) of East Java, Indonesia. The region of APNP wide is $\pm 62,000$ ha: East to North East side face on Bali strait, South West to South East face to Indian ocean. The coordinate sites are Bedul Mangrove (BDL M) S $08^{\circ} 35^{\prime} 40.2^{\prime}$ E $114^{\circ} 15^{\prime}$ 41.4”, Bedul Beach (BDL B) S 08 36' 07.3" E $114^{\circ} 15^{\prime}$ '29.4", Trianggulasi (TRG) S 08 39' 23.0" E $114^{\circ} 21^{\prime} 35.3^{\prime \prime}$, Pancur (PCR) S 08 40' 55.1" E $114^{\circ}$ 22' 22.9', Plengkung (PLE) S $08^{\circ} 43^{\prime}$ 46,7' E $114^{\circ} 21^{\prime}$ '04,2”, Jatipapak (J PPK-mangrove) $08^{\circ} 32^{\prime}$ 08.1' E $114^{\circ} 22^{\prime}$ '23.4”, Perpat (PER) S $08^{\circ} 36^{\prime} 18.8^{\prime \prime}$ E $114^{\circ} 25^{\prime}$ 24.9”, Slenggrong (SLE) S 08 38' 03,6" E $114^{\circ} 26^{\prime}$ '31,8', Tanjung Sekeben (T SEK) S $08^{\circ} 37^{\prime} 25.5$ E $114^{\circ} 28^{\prime} 00.5^{\prime \prime}$, Tanjung Batu (T BT) $\mathrm{S} 08^{\circ} 41^{\prime} 13.9^{\prime \prime} \mathrm{E} 114^{\circ} 35^{\prime} 11.0^{\prime}$ ". Administratively, the study site is located in Tegaldlimo Sub-district, Banyuwangi District, East Java Province, Indonesia. The study sites are shown on Figure 1.

Slenggong and Perpat are muddy beaches with seagrass towards the open sea and coral reefs. Slenggrong consists of magnificent black sand, which turns to mud due to the seawater. Slenggrong also has mangrove trees. Prepat beach ranges from very fine white sand to coarse silt and also has mangroves. The sand and silt turn into a sticky mud in several places. Although APNP is a conservation region, some sites are open to the public as part of ecotourism: Pancur, Bedul (mangrove and beach) and Plengkung (rarely open to the public). Tanjung Sekeben and Tanjung Batu are closed to the general public as they are far-flung and hard to reach.

\section{Procedures}

We used purposive sampling to determine the locations, shore tracking, and multi-plot quadrats for the gastropod population, with three transect lines per site and 20-25 plots per line (Tongco 2007). The distance between the transect lines was 100-300 m, depending on the site. The plot size was $4 \mathrm{~m}^{2}$. We observed during the day at very low tide (from July 2016 to December 2017). The distribution pattern was based on the cumulative taxa frequencies (families and orders). We divided the beach area into three subzones (upper, middle, and lower) across the intertidal zone (the size of transect line depended on the beach type). First, we divided the line transect into four parts. The first part, in the border of the terrestrial zone, was marked as the upper subzone, the second and third parts as the middle subzones, and the last part as the lower subzone (Figure 2). We measured water physicochemical parameters including water temperature, air temperature, sediment temperature, $\mathrm{pH}$, salinity, water dissolved oxygen, air dissolved oxygen, $\mathrm{CO}_{2}, \mathrm{PO}_{4}$, and $\mathrm{NO}_{3}$. All environmental factors were measured in situ. Gastropod species were identified using reference and identification monographs and literature (Dance 1992; Poutiers 1998; Dharma 2005; Eichhorst 2016), online shell guide catalogues, such as Hardy's Internet Guide to Marine Gastropod ( $\&$ Near Classes) and the World Register of Marine Species (WoRMS), and confirmed using paratypes of the shell collection in the Museum of Natural Sciences in Brussels, Belgium. 


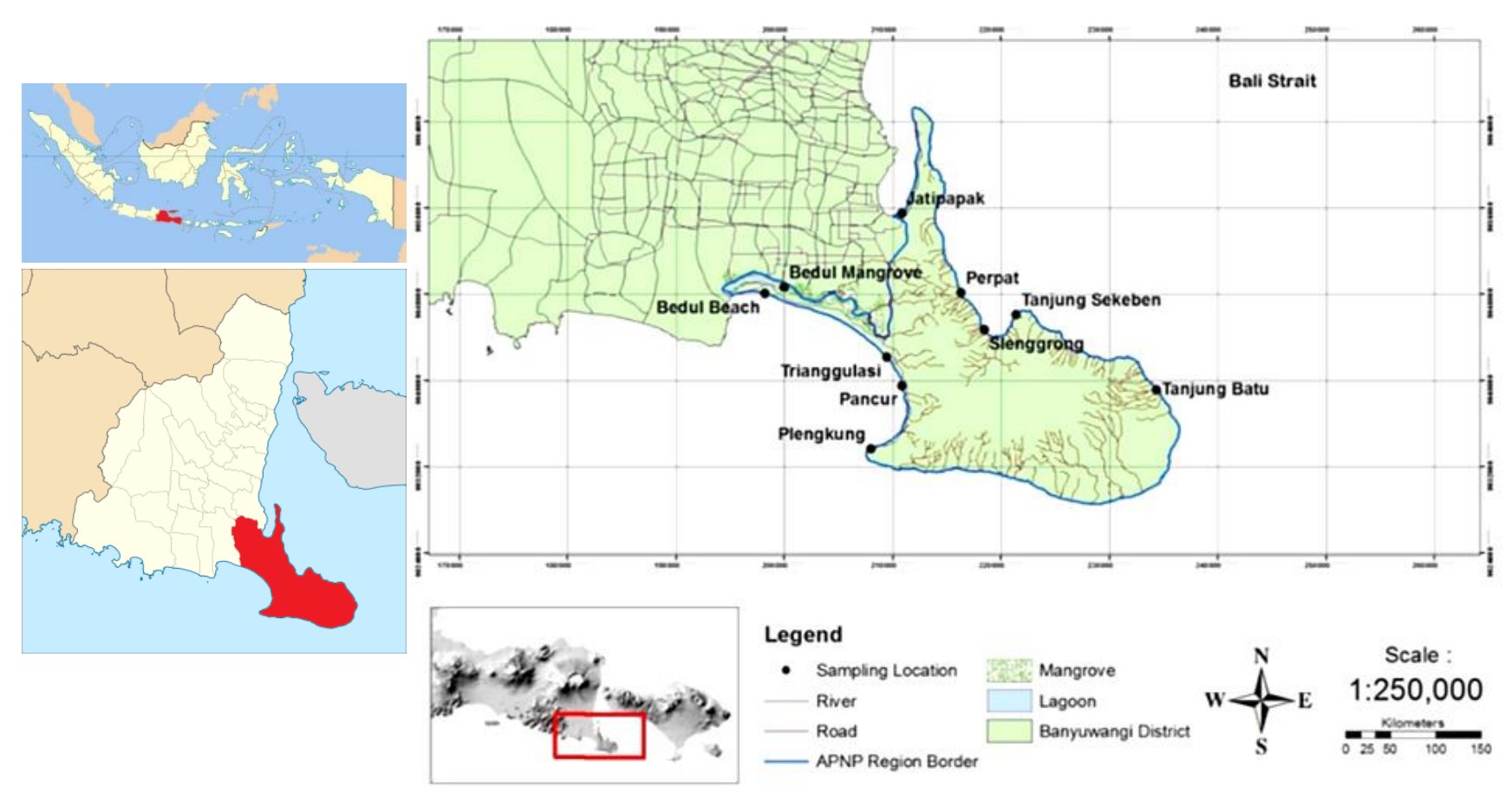

Figure 1. The region of Alas Purwo National Park (APNP), East Java, Indonesia and study sites

\section{A}
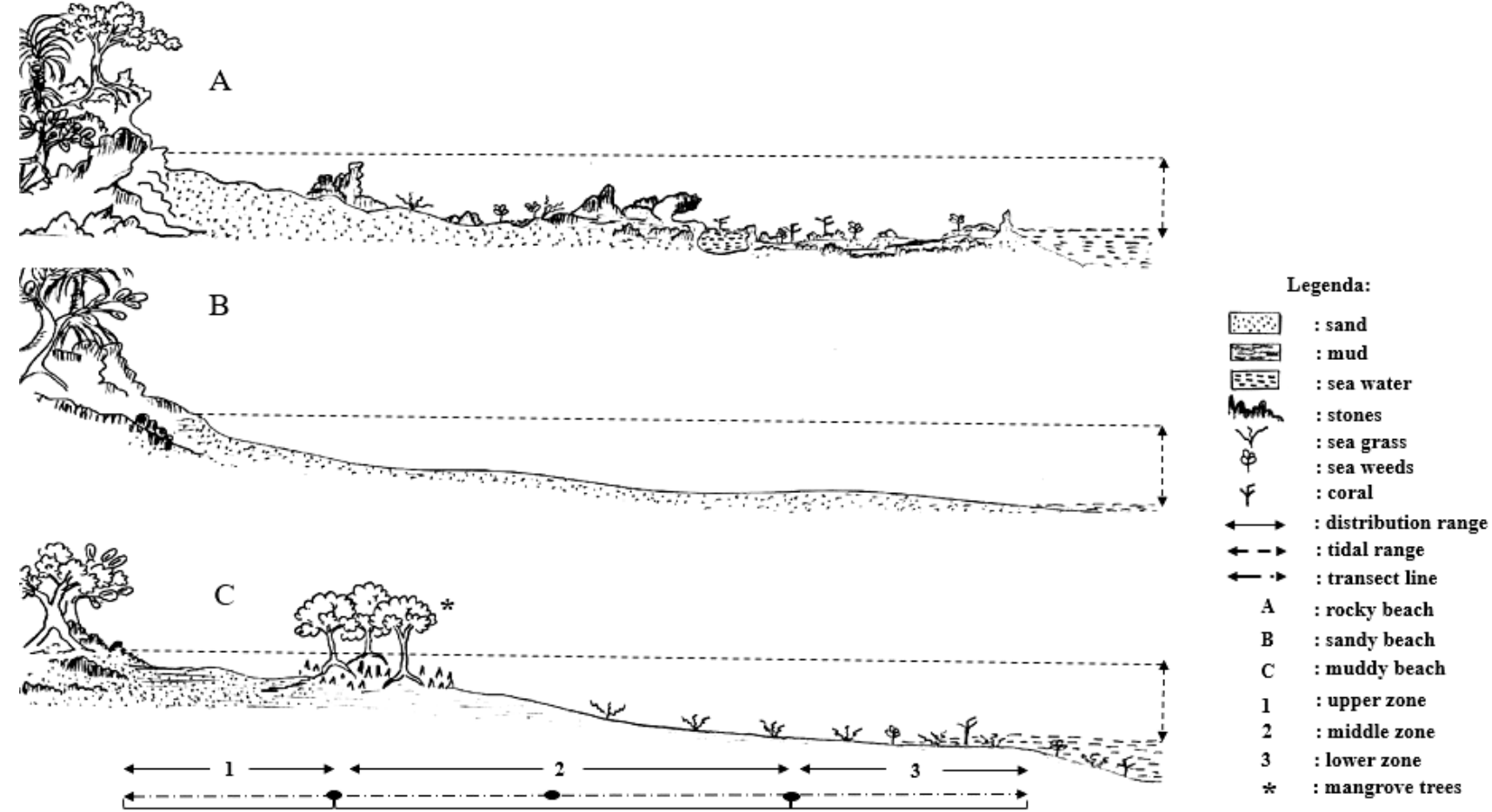

Figure 2. Beach types and three regions of intertidal zones in Alas Purwo National Park, East Java, Indonesia: A. Rocky shore: Pancur, Plengkung, Tanjung Sekeben and Tanjung Batu; B. Sandy beach: Bedul and Trianggulasi; C. Muddy beach: Perpat and Slenggrong. Tidal range was between 0.500 and $2.500 \mathrm{~m}$; the length of intertidal zone (upper to lower) on rocky shore: $30-445 \mathrm{~m}$; sandy beach: 29 $116 \mathrm{~m}$ and muddy beach: $99-245 \mathrm{~m}$ 


\section{Data analysis}

\section{Intertidal gastropods diversity}

The diversity was analyzed using the Shannon-Wiener diversity index, taking into account the number of specimen (individuals) as well as the number of taxa. The formula of the Shannon-Wiener index (Harper 1999) is:

$$
\mathrm{H}^{\prime}=-\sum_{i} \frac{n i}{n} \ln \frac{n i}{n} \text { and for some measurements, we used }
$$
the Simpson's diversity index: $\mathrm{D}=\sum_{i}\left(\frac{n i}{n}\right)^{2}$

We used PAST 3.22 software to show the diversity profile (Hammer et al. 2001: updated in December 2018), autocorrelation, individual rarefaction and corresponding analysis (CA) for drawing family distributions. Order and family taxa distributions were patterned by their frequency. Environment quality factors in all sites were evaluated using principal component analysis (PCA).

We established the diversity profile using Tothmeresz' (1995) method. This profile compares the distributions of all the samples. It is caused by the arbitrary choice of the diversity index. We compared the diversity indices to make sure that the diversity ordering in robust. We used the Reyni index in which the parameter $\alpha$ is the central value. For $\alpha=0$, this function gives the total species number, $\alpha=$ 1 (in the limit) gives an index proportional to Shannon's index, while $\alpha=2$ gives an index which behaves like Simpson's index.

$$
\begin{aligned}
& \mathrm{S} \text { is number of taxa and } \mathrm{pi}=\frac{n i}{n} . \\
& \exp (\mathrm{H} \alpha)=\exp \left[\frac{1}{1-\alpha} \ln \sum_{i=1}^{s} p i^{\alpha}\right]
\end{aligned}
$$

We used individual rarefaction to compare the species richness in the different samples. It's based on the algorithm used by Krebs (1989), using the gamma function applied by Adrain et al. (2000). It shows the number of taxa in the samples of all sites, including the highest and lowest observations.

$$
\begin{aligned}
& \mathrm{E}(\mathrm{Sn})=\sum_{i=1}^{S}\left[1-\frac{\left[\begin{array}{c}
N-N i \\
n
\end{array}\right]}{\left[\begin{array}{c}
N \\
n
\end{array}\right]}\right] \\
& \mathrm{V}(\mathrm{Sn})=\sum_{i=1}^{S}\left[\frac{\left[\begin{array}{c}
N-N i \\
n
\end{array}\right]}{\left[\begin{array}{c}
N \\
n
\end{array}\right]}\left[1-\frac{\left[\begin{array}{c}
N-N i \\
n
\end{array}\right]}{\left[\begin{array}{c}
N \\
n
\end{array}\right]}\right]\right]+2 \\
& \sum_{j=2}^{S} \sum_{i=1}^{j-1}\left[\frac{\left(\begin{array}{c}
N-N i-N j \\
n
\end{array}\right)}{\left(\begin{array}{c}
N \\
n
\end{array}\right)}-\frac{\left(\begin{array}{c}
N-N i \\
n
\end{array}\right)\left(\begin{array}{c}
N-N j \\
n
\end{array}\right)}{\left(\begin{array}{l}
N \\
n
\end{array}\right)\left(\begin{array}{c}
N \\
n
\end{array}\right)}\right]
\end{aligned}
$$

$\mathrm{N}$ is the total number of individuals in the sample, while $\mathrm{S}$ is the total number of species (taxa), and $\mathrm{Nj}$ is the number of individuals of $i$ species. In addition, the $E(\mathrm{Sn})$ is the expected number of species in $n$ (a sample of species) and $\mathrm{V}(\mathrm{Sn})$ is the variance. The confidence interval is $95 \%$, based on 2,000 replicates.

\section{Intertidal gastropod distribution}

We used the Morisita index to determine the spatial distribution of species, while the corresponding Analysis (CA) showed the taxa (family) distribution that applied by the ordination technique analysis. It's similar to the principal component analysis. We compared the number of taxa across all datasets/samples. It's used to predict the species which have unimodal responses to the niche. The $\mathrm{CA}$ is a composite diagram assuming a linear response. The association would follow this plotting if the taxa are 'well behaved' (Hennebert and Lees 1991). The order distribution was then added to the intertidal zones represented in Figure 2.

Morisita Index(Krebs 1999):

$$
\begin{aligned}
& \mathrm{Id}=\mathrm{n} \frac{\left(\sum x i^{2}-\sum x i\right)}{\left(\sum x i\right)^{2}-\sum x i}(\text { Morisita 1962) } \\
& M u=\frac{x^{2} 0,975-n+\sum x i}{\left(\sum x i\right)-1} M c=\frac{x^{2} 0,025-n+\sum x i}{\left(\sum x i\right)-1}
\end{aligned}
$$

Morisita index degrees (Smith-Gill 1975):

$$
\begin{aligned}
& \text { Ip }=0.5+0.5\left(\frac{I d-M c}{n-M c}\right) \text { if } I d \geq M c>1 \\
& \mathrm{Ip}=0.5\left(\frac{I d-1}{M c-1}\right) \text { if } M c>I d \geq 1 \\
& \mathrm{Ip}=-0.5\left(\frac{I d-1}{M u-1}\right) \text { if } 1>I d>M u \\
& \mathrm{Ip}=-0.5+0.5\left(\frac{I d-M u}{M u}\right) \text { if } 1>M u>I d
\end{aligned}
$$

Note: $\mathrm{n}$ for plot sample number; $\mathrm{x}$ for individual number; if Ip $<0$ for a uniform distribution; Ip $=0$ for a random distribution and $\mathrm{Ip}>0$ for a clumped distribution. The degrees (Ip) derived from the Morisita index (Id) were used as an indicator of spatial distribution.

\section{RESULTS AND DISCUSSION}

\section{Intertidal gastropod diversity in APNP}

We register 22,481 specimens gastropods consisting of 148 species, 60 genera, 36 families, and 10 orders. We have not included a list with the names of the species in this report, but such a list can be obtained for specific identification purposes by contacting the authors. Pancur beach boasted the greatest diversity, with 67 species, while Trianggulasi and Bedul beach had the lowest diversity with only two species (Tabel 1). Of the 148 species, 20 were Neritidae and 19 were genus Nerita. Nerita was present on all the sites, excluding the sandy beaches.

The Shannon Diversity Index (H') value shows the diversity: $\mathrm{H}^{\prime}<1=$ low, $1<\mathrm{H}^{\prime}<3=$ moderate and $\mathrm{H}^{\prime}>3=$ high. The highest value of $\mathrm{H}^{\prime}$ was in Pancur: 3.271, likewise for the Simpson Diversity Index (D): 0.947 (Figure 3). This means that, of all the sampled sites, Pancur beach has the highest gastropod diversity. Pancur is a rocky shore but also has sand in its upper zone (type A). The two mangroves which we investigated are also shown: Bedul mangrove $\mathrm{H}^{\prime}=2.138$ and $\mathrm{D}=0.837$ and Jatipapak mangrove $H^{\prime}=1.499$ and $\mathrm{D}=0.718$. We discovered 20 species in Bedul mangrove and 12 species in Jatipapak mangrove. Trianggulasi and Bedul beach are sandy beaches. Both sites contained Oliva oliva taeniata Link, 1807, while O. tigridella Dulcos, 1835 was found on Bedul beach and $O$. todosina Duclos, 1840 on Trianggulasi beach. Bedul flat is part of a lagoon that opens up at low tide. 
Bedul lagoon had $\mathrm{H}^{\prime}=0.955$ and $\mathrm{D}=0.467$. We found six species on this site. The Shannon-wiener and Simpson diversity index values of gastropods in Perpat and Slenggong beaches were estimated as 1.703 and 0.679 for Perpat beach, and estimated as 1.620 and 0.678 for the Slenggong beach. We discovered 24 species in Perpat and 33 species in Slenggrong beaches. However, a plethora of Nassarius could be found on both sites. The seagrass community was located on the first and second transect of Plengkung, and in small areas of Pancur, Perpat, and Slenggrong. The seagrass community was not found in Tanjung Sekeben and Tanjung Batu. It was located from the middle to lower zone

The diversity profile of Figure 4 explained the taxa diversity of $H^{\prime}$ (on $\alpha=1$ ) and $D$ (on $\alpha=2$ ). Individual rarefaction shows the abundance of individuals on the sites and taxa diversity. It's possible that the taxa diversity is low while the individual number is abundance; hence we need to show the images together. The beaches with abundant of individuals number of gastropod communities were found in Pancur (9055 individuals), Plengkung (3936 individuals), Bedul mangrove (2871 individuals), Jatipapak (2297 individuals), Tanjung Batu (1569 individuals), Slenggrong (1332 individuals). On the hand, the beaches with less abundant gastropods were found in Tanjung Sekeben (754 individuals), Perpat (460 individuals), Bedul (90 individuals), Trianggulasi (64 individuals), and Bedul lagoon flat (310 individuals) (Table 1).

\section{Intertidal gastropod distribution in APNP}

The degrees (Ip) values of Morisita index (Id) were used as an indicator of the spatial distribution pattern of gastropods. At all sampled sites, the spatial distribution patterns of gastropods were weakly clumped. The highest Ip score was found in beaches of Tanjung Batu (0.165), following by Bedul lagoon flat (0.129) and Jatipapak (0.119). Since Ip values exceeded to zero for all three sites, this indicates clumped distributions. The Ip value of gastropods distribution pattern for most of sampled sites were nearly to zero including Trianggulasi (Ip $=0.066$ ), Plengkung $(\mathrm{Ip}=0.060)$, Perpat $(\mathrm{Ip}=0.051)$, Bedul mangrove (Ip $=0.050)$, Slenggrong $(\mathrm{Ip}=0.041)$, Pancur (Ip $=0.028)$, Tanjung Sekeben $(\mathrm{Ip}=0.018)$ and Bedul $(\mathrm{Ip}=$ 0.016). Those Ip values indicate weakly clumped, or even random distribution pattern of gastropods in these beaches.

Figure 4 notes the frequency of every species in their subzone niche. The pattern shows the horizontal distribution of the gastropod community up to the sea. Species have their specific niche or may share it with other species, which is called niche overlap. The species we met in each plot were found in a suitable place, supported by habit and survival effort from drought stress at low tide. The corresponding analysis (Figure 5) was presented for elucidation the distribution pattern of gastropods in their niche. The graphs below indicate in which subzones of families and orders were located. If a family or order was found in two subzones, it's located on the connecting convex hull lines of the graph below. However, if a family or order was distributed in all subzones, it's located in the middle of the convex hull frame. A specific subzone means the family or order was located in one subzone only. The gastropods found in each plot of this study indicated their suitable habitat that might be supported the routine and survival effort from drought stress at low tide of gastropods.

Figure 6 describes the Principal component analysis (PCA) of the chemical-physical condition of sampled sites. The highest salinity was found in Tanjung Batu (35\%) and the lowest salinity was found in Bedul lagoon (21.67\%o). The sites of Bedul, Trianggulasi, Pancur, and Plengkung beaches were located in the same direction (Figure 6). The environmental conditions of water, sediment, and air temperature varied, and the overall temperature was found in normal condition $\left(27-32^{\circ} \mathrm{C}\right)$. The highest temperature (measured at noon) was in Pancur and Jatipapak beaches. Nontji (2007) noted that the temperature in the intertidal zone can reach $35^{\circ} \mathrm{C}$ in the daytime, especially at low tide. Based on the tide tables of Banyuwangi region of 20162017 , the tide range in this site is $0.500-2.500 \mathrm{~m}$. Water acidity degrees $(\mathrm{pH})$ ranged 6.397-11.333. The lowest $\mathrm{pH}$ was found in Bedul beach, and the highest was found in Pancur beach. According to Nybakken (1992), dissolved oxygen, nutrient and $\mathrm{pH}$ are not direct influences on the intertidal organism community, but it becomes an important factor for some conditions. Water dissolved oxygen ranged $21.100-15.567 \mathrm{mg} / \mathrm{L}$ and air dissolved oxygen ranged 16.567-24.767 $\mathrm{mg} / \mathrm{L}$. However, the $\mathrm{CO}_{2}$ concentration in water ranged $0.083-0.868 \mathrm{mg} / \mathrm{L}$, and the lowest was in Plengkung beach, while the $\mathrm{PO}_{4}^{-}(\mathrm{P})$ in water concentration ranged $0.100-2.000 \mathrm{mg} / \mathrm{L}$.

\section{Discussion}

Marshall and Banks (2013) mentioned that the conditions of beaches are vulnerable to change. The cause of these sensitive conditions stems from both a naturally dynamic physical environment and human-made impacts. According to Jones et al. (2009), climate change, erosion, resource depletion, shoreline hardening, off-road vehicles, beach cleaning, pollution, fisheries, sand removal (mining), and introduced species are the principal threats to beaches. Following Brewer's argument (1993) about habitat selection, if the habitat is suitable and acceptable, animals will settle, establishing territories and reproducing offspring, but if the habitat is unacceptable, animals will return to the first stage of exploring their environment in search of a satisfactory area. Human disturbance should not be a problem in these places as they are protected. However, ecotourism could be responsible for some disruption. Rumahlatu and Leiwakabessy (2017) studied a similar beach type on Ambon around the same time that this study was carried out. They found 65 species and a Shannon index $\left(\mathrm{H}^{\prime}\right)$ of \pm 3.6 . Lower diversity index scores were found on the rocky shores: Plengkung $\mathrm{H}^{\prime}=2.643$, Tanjung Sekeben $H^{\prime}=2.612$, and Tanjung Batu H' $=1.885$ (the lowest score). This means that the gastropod diversity of those sites was low to moderate but the number of species still significantly higher than that of Ambon Island (Rumahlatu and Leiwakabessy 2017) and that of the Wakatobi Islands, the latter having only 10 species (Rahmayanti et al. 2018). 
Table 1. Intertidal gastropod community in Alas Purwo National Park, East Java, Indonesia

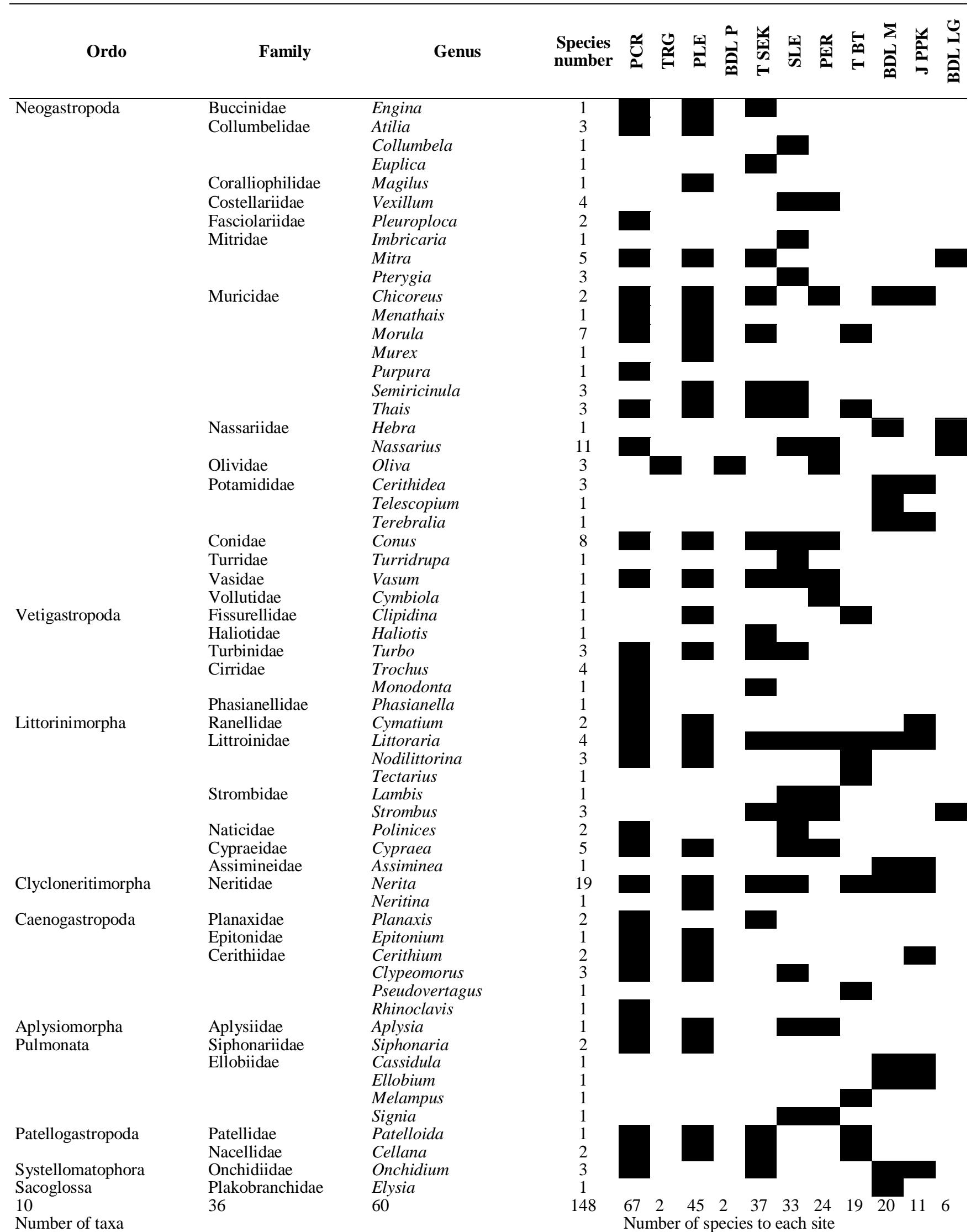

Note: The species' names are not represented in this table. For specific identification purposes, please contact the authors at their personal e-mail addresses listed above. $\mathbf{m}=$ present in study site. Total number of individuals: 22,481 specimens 

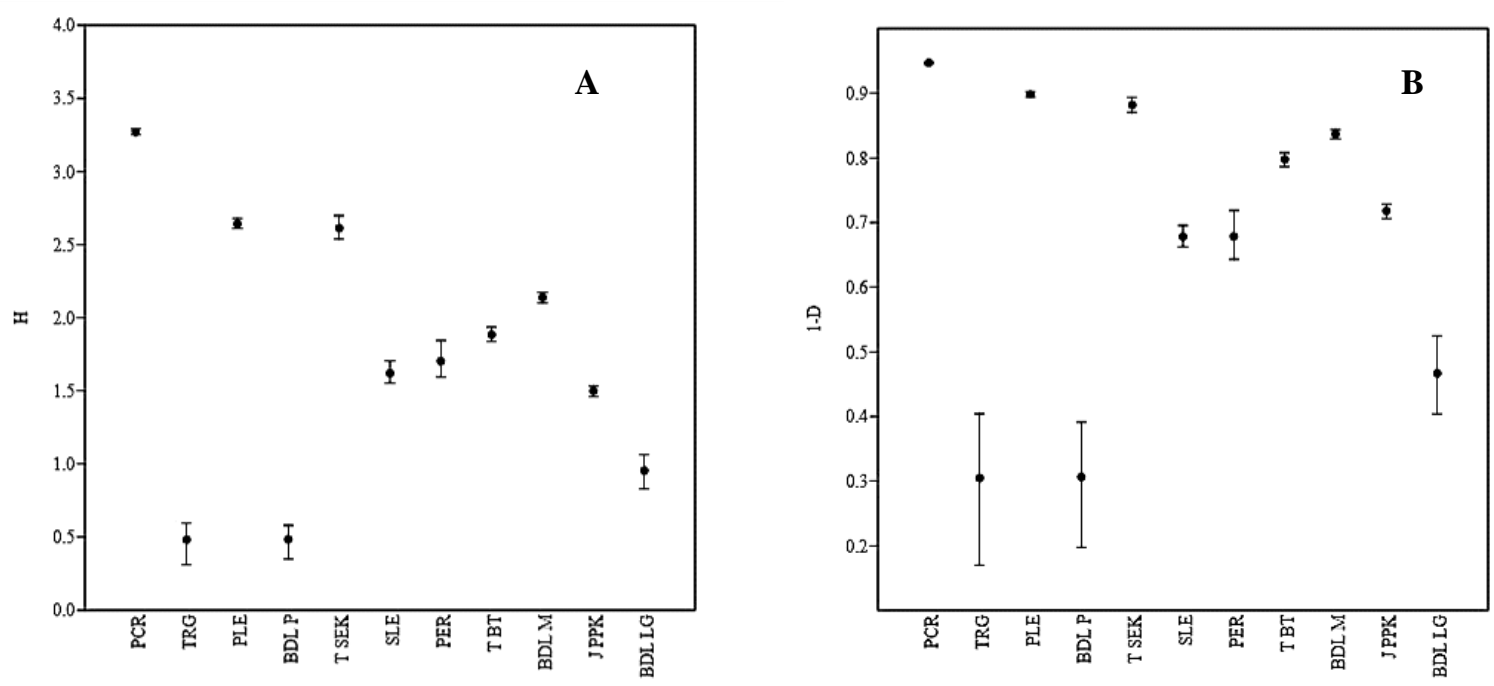

Figure 3.A. Shannon Diversity Index, and B. Simpson Diversity Index of Alas Purwo National Park, East Java, Indonesia gastropods community
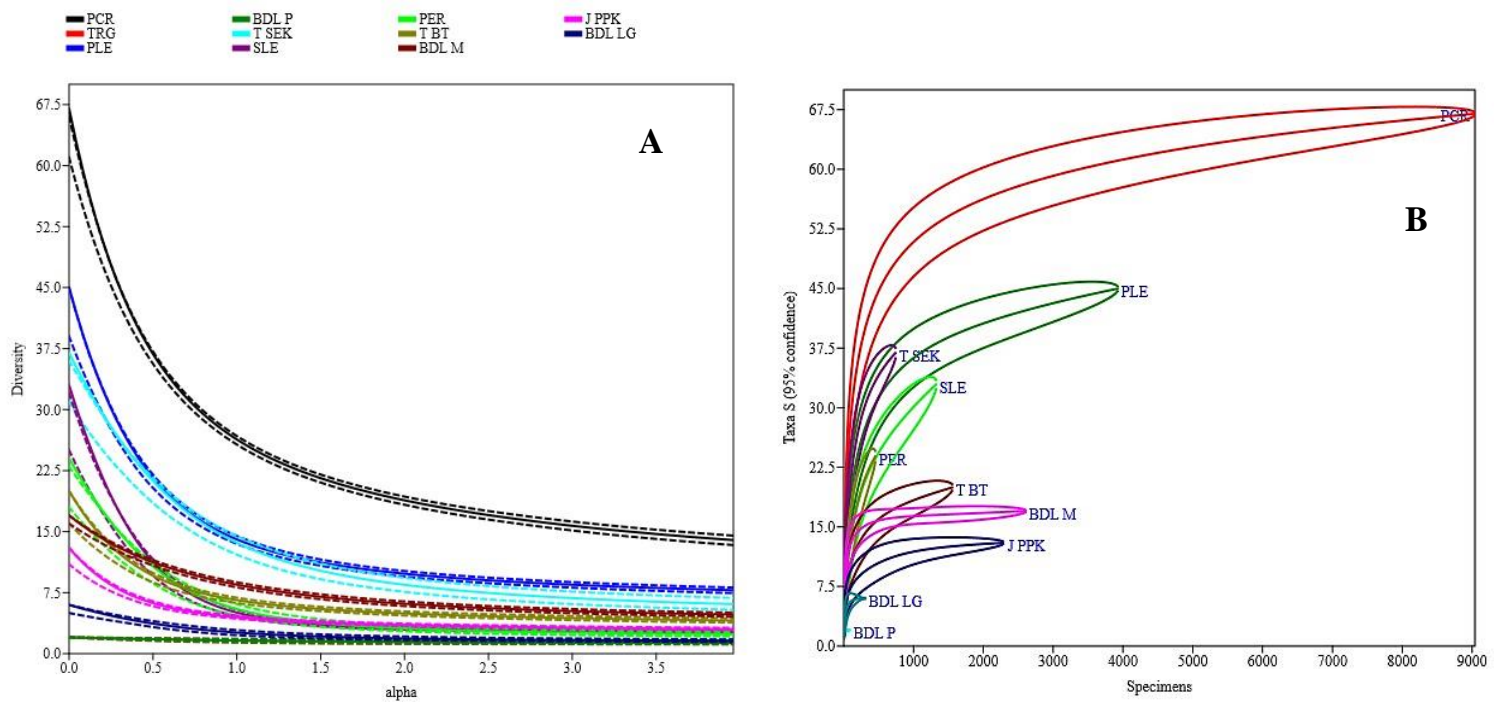

Figure 4. A. Diversity profile, and B. Individual rarefaction of Alas Purwo National Park, East Java, Indonesia gastropods community
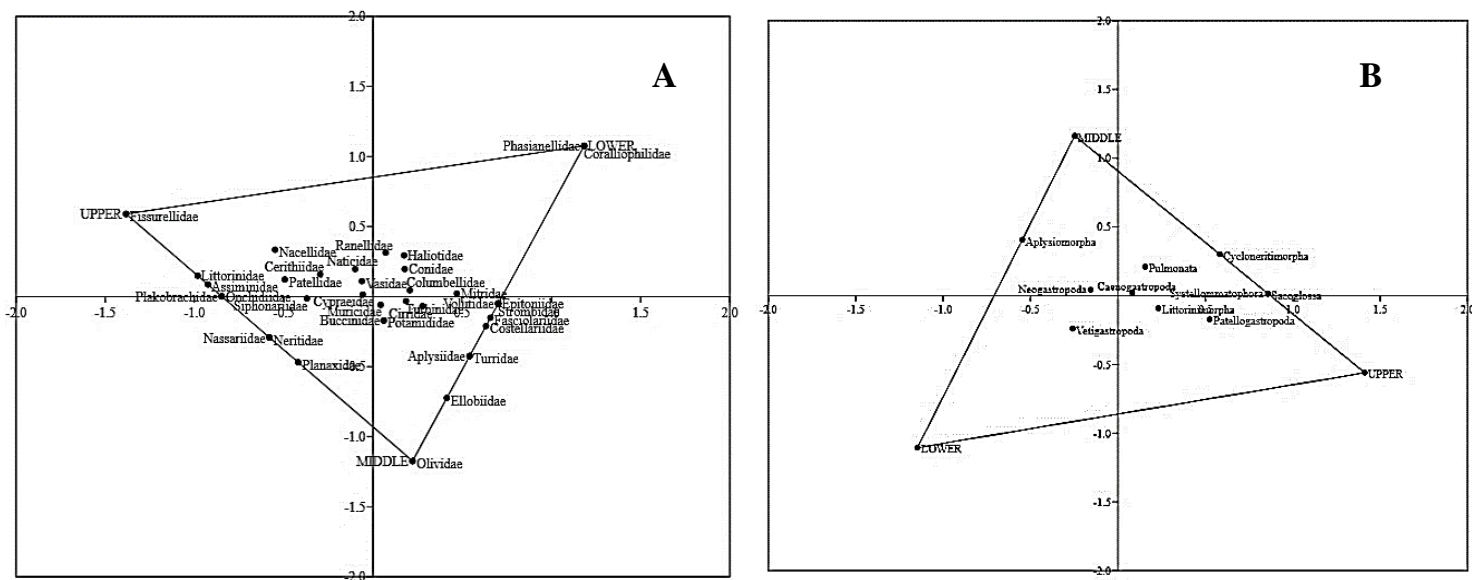

Figure 5. Correspondence analysis of taxa: A. Family distribution, and B. Order distribution in each Alas Purwo National Park, East Java, Indonesia subzones 


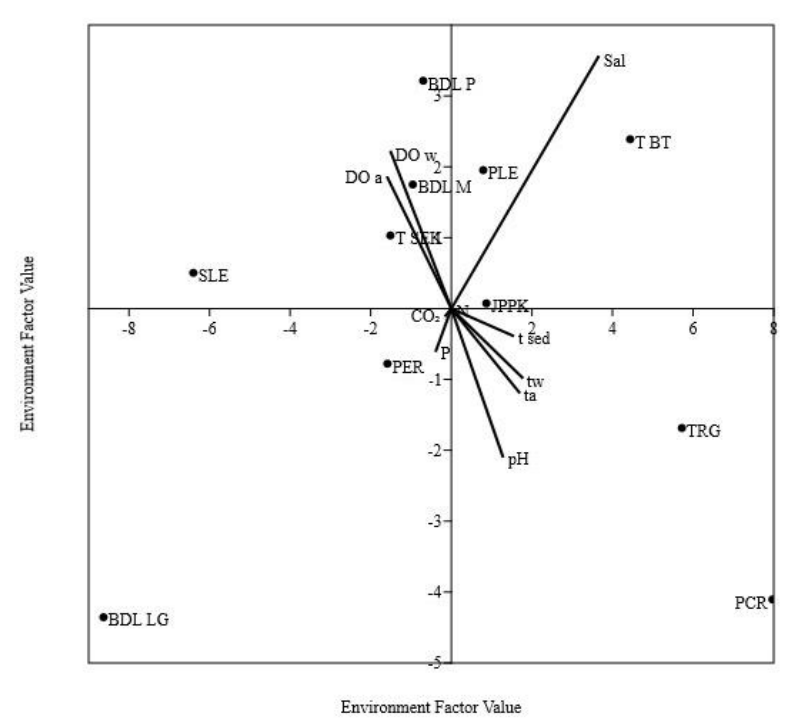

Figure 6. Principal component analysis of environment factor value

According to Rodríguez-Revelo (2018), ecosystem services provided by beaches and coastal dunes are used in order to design and implement adequate management practices that conserve the ecosystem, but we did not find sand dunes in APNP, not even in Trianggulasi nor Bedul, which are sandy beaches. Pancur has more diversity than other rocky shores, $40.54 \%$ of all species in all sites. Gladstone et al. (2007) described biodiversity on fifteen rocky shores. He discovered 230 species, representing 74\% of all species and $48 \%$ of rare species. It is likely supported by a coral rock which creates shelter and hiding places during low tide. The shade in these pools is perfect to protect organisms from drying out, which is the most serious problem facing life in the intertidal zone. Rocks act as barriers from waves and wind, and animals can crawl under them to escape predators. The weakness from low tide stress makes them easy prey. During our fieldwork, we discovered a few gastropods hunting others: Thais tuberosa (Röding 1798) hunting Siphonaria javanica (Lamarck 1819). Thais belongs to Muricidae. According to Peharda and Morton (2005), Muricidae acts as a predator family in relation to other gastropods and Bivalvia. Muricidae as predators have also been proven by Tan (2008) and it as the predator is recognized even in the fossil record (Cenozoic age). Muricidae were strongly present in all subzones. Predators are necessary for maintaining a healthy population and ecosystem. The sites sampled in this research illustrate that the rocky shore has higher diversity than other beach types. Rocky shores are very important in providing homes to many organisms (Marshall and Banks 2013). Seaweed covered the ground from the middle to lower subzones. The seaweed community is a food source for many organisms in this habitat (Nybakken 1992). Pancur also supports a sandy shore above the rocky area.
Fine sand here is covered by seagrass. We discovered nine burrowing habit species. The big three abundance species with a burrowing habit are Nassarius acuticostus (Montrouzier 1864), Rinoclavis sinensis (Gmelin 1791) and Conus coronatus (Gmelin, 1791). The burrowing habit of gastropods was studied by Vanagt et al. (2008) and Vermeij (2017). Rhinoclavis sinensis prefer to burrow in small sand pockets on reefs. The small sand pocket of this site was on the front of the upper subzone in between the rocks and in sandy and rocky areas overgrown by seagrass. Neritidae mostly lives on seaweed (Leite et al. 2009) and seagrass (Unabia 2011; Rossini et al. 2014). They were distributed from the upper to middle subzone, this results were supported by Alavi-Yeganeh (2016). He studied Neritidae on the northern coast of Iran to estimate the distribution of four Nerita species and their size mass. The predators were distributed from the upper to lower subzones, while herbivores were distributed where food was available (Figure 7).

We discovered five species of Nerita in Pancur out of 19 Nerita species in all sites. As herbivores, Nerita was distributed where seaweed and seagrass were available. Nerita plicata Linnaeus, 1758 always settled on the rocks of the upper subzone. The settling of organisms in their respective habitats are interconnected: they depend on one another. Hay (1997) described the habit of feeding on calcified seaweeds of some herbivores as both complex defense mechanisms of seaweed and gastropod predator behavior, trophic relationships and valuable as habitats. Seaweed flourishes as grazing avoid overgrowing. It's a safe place to hide from predators and the calcium in seaweed thalli supplies calcium needs. The relationship between seaweed and gastropods is thus both complex and valuable.

Coexisting species on sandy beaches use other sources for a living (e.g., detrivores, suspension feeders, deposit feeders) and also different reproductive modes (e.g., pelagic larvae, brooding). They occupy different zones of the intertidal area (Brazeiro 2001). Sandy beaches seem poor in organic matter. Diversity in Bedul beach and Trianggulasi were very low, but Defeo et al. (2008) mentioned that invertebrates (Mollusca: gastropods included) could reach high abundance (ca. 100,000 ind $/ \mathrm{m}$ ) and biomass $(>1000 \mathrm{~g} / \mathrm{m})$, especially in dissipative to intermediate beach types in temperate zones. Composition and abundance of invertebrate aggregation in sandy beaches are controlled primarily by the physical environment, intertidal swash and sand conditions. The Oliva oliva taeniata, O. tigridella, O. todosina belong to Olividae family and distributed in sandy beaches, while the only three species were found in this area because of the rocky shore beach is the extreme habitat for borrowing gastropods. The Olividae is one of the burrowing habit gastropods (Vanagt et al. 2008), and are scavengers and deposit feeders, and therefore rocky shore beach is the unfavorable area for borrowing gastropods. 


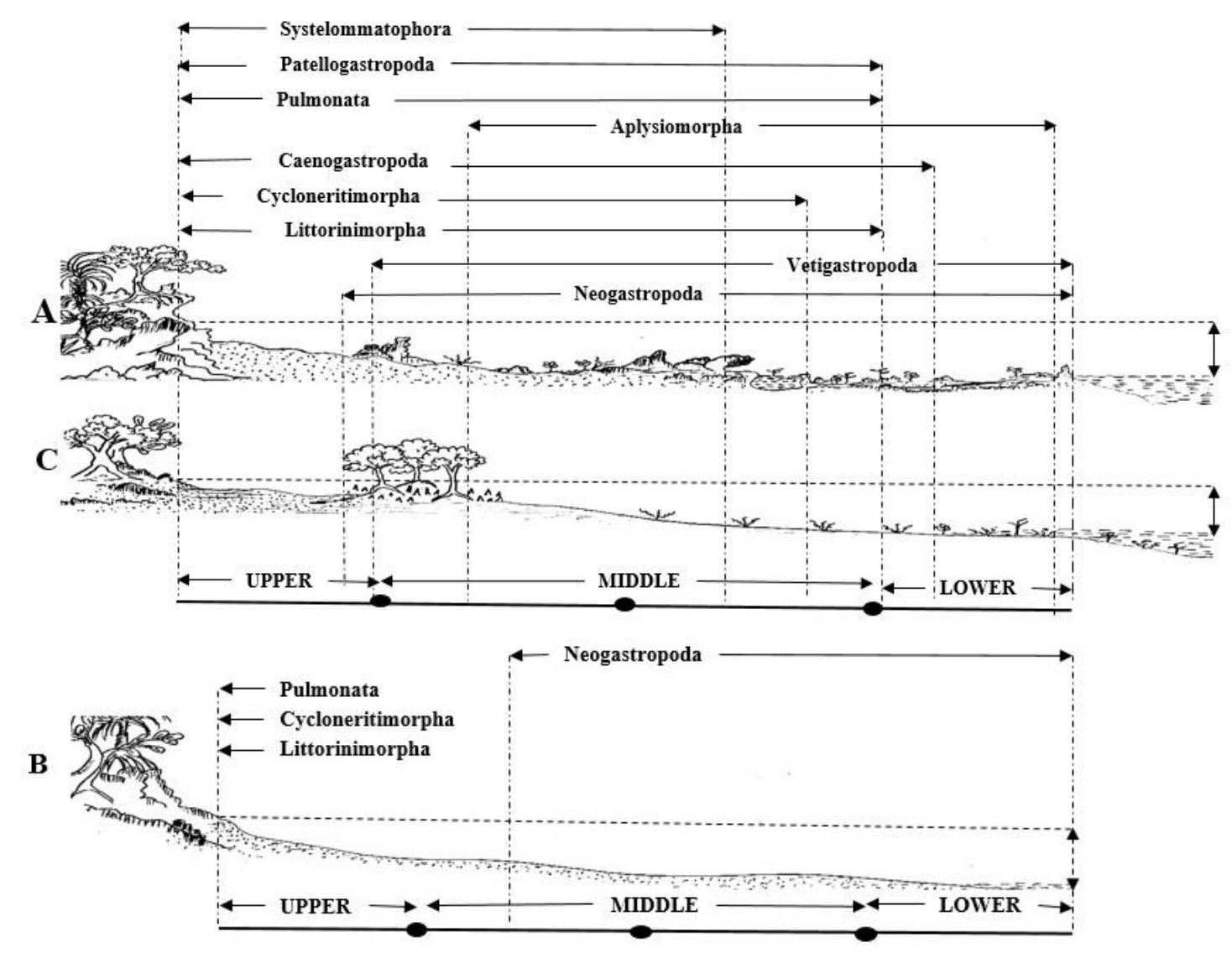

Figure 7. Horizontal taxa distribution pattern of intertidal gastropods in Alas Purwo National Park, East Java, Indonesia

This study clearly described the beaches with muddy and seagrass beds having higher diversity than sandy beaches. This is because the seagrasses provide shelter and substrate for many organisms (fauna and flora), and these habitats are important nursery and feeding areas (Baeta et al. 2011). Perpat site is the beach with a white muddy shore as the bed of the seagrass community, but Slenggrong beach has black mud as a seagrass bed. The seagrass is a vast food source of gastropods (Holzer et al. 2011a; 2011b; Fong 2018). The genus of Nassarius was abundance in both sites including Nassarius pullus and N. jacksonianus. De Lucena et al. (2012) noted that Nassarius has a scavenger and burrowing habit (Azeda et al. 2013). Muddy habitat supports Nassarius to dig and burrow through the sediment and search of detritus. Dorgan et al. (2006) explained the muddy sediments are adhesive and resist deformation. Muds are elastic solids that fracture under small tensile forces exerted by burrowers. A great many anatomical features of burrowers can now be understood analogously. Burrowers need to exert force through peristalsis to make their way through these sediments. Kawaroe et al. (2016) described the gastropod communities in four sites of Indonesia's seagrass ecoregions. Several species such as Lambis lambis and Conus eburneus are seagrass gastropods. In addition, Smaragdia viridis is true grazers of seagrass (Holzer et al. 2011a), and showed high abundance in the seagrass bed. Mud snails are grazed not only on seagrass but also on seaweed of Ulva spp. (Arau'jo et al. 2015). The existence of parasitic gastropods was noted by Hoeksema and Gittenberger (2008) and Nekhaev (2011), and we found one parasitic gastropod of Melanella randolphi on sea stars that habited in the middle subzone of the beach types $\mathrm{A}$ and $\mathrm{C}$.

Telescopium telescopium and Elysia leucolegnote were present in Bedul mangrove while Cerithium coralium were in front of the border of the mud bed near mangrove trees in Jatipapak beach. The diversity of gastropods in APNP differs seemed to different as of the study reported by Irma and Sofyatuddin (2012). They found gastropod communities in Aceh beach after three years of the tsunami, although the gastropods of Nassarius olivaceus and Littoraria scabra (Linnaeus 1758) are present at both APNP and Aceh beaches. The L scabra are common gastropods that habited on the trunk of Sonnerantia alba (Smith) in Perpat and Slenggrong beaches. Alvaro (2007) reported that L. scabra is the common species of the genus Littoraria in mangroves ecosystem. Here, it seems that $L$. scabra is following a migration pattern from the mangrove area downwards to the tide. Meanwhile, the only species of Plakobrachidae of E. leucolegnote was found in Bedul mangrove. According to Swennen (2011) and Takano et al. (2013), E. leucolegnote is one of two Elysia species as specific Saccoglosan in mangroves, aggregated on soft mud in shallow, shaded pools during low tide. 
The present results showed clearly distribution of gastropods in the coastal zone. The gastropods as the member of Fissurelidae family are specific in the upper zone, while the gastropods belonging to Olividae family are colonized in the middle subzone. On the other hand, the gastropods belonging to Phasianellidae and Coralliophilidae families are habited in the lower subzone. However, most of gastropods species belonging to Neogastropods order are showed wide distribution areas from the upper to the lower subzone. Other gastropods belonging to Coralliophilidae and Olividae families located specifically in subzones only. Mostly, the gastropods as the member of Olividae family live in the deep sea, but they were found exclusively in the middle subzone in sampled sites of the present study. Niamaimandi et al. (2017) also found them in the intertidal zone. According to the CA (Figure 7), the horizontal taxa distribution pattern on APNP beach is described clearly. The specific distribution pattern of gastropods taxa showed as a type $B$, because it dominated by Olividae order Neogastropods, and are quite rare in the upper subzone. There are 71 species of Neogastropod order that distributed from the upper to the lower zone. The biggest family is Neritidae and belongs to Neritimorpha order. Moreover, the 19 species of Neritidae family are distributed from the upper to middle subzone, while the gastropods as the member of Aplysiomorpha are distributed from the middle to lower subzone. However, the temporal dynamic distribution of gastropods must be evaluated (Moreira et al. 2010). Meanwhile, the analyzing of spatial distribution an organism is significantly affected by the estimation method (Requia 2018). The information on the distribution pattern of organisms could be useful for environmental assessments or investigations into the effects of anthropogenic disturbance based on their niche in this ecosystem.

In conclusion, high diversity of gastropods was found in APNP that consisting of 148 species, 60 genera, 36 families, and 10 orders. The Neogastropoda is the biggest order of gastropods with 71 species. The larger gastropods are members of the Neritidae and Muricidae families, and 19 species of Neritidae family are a member of Nerita genus. The highest diversity index ( $\left.\mathrm{H}^{\prime}\right)$ was found on Pancur rocky shore: $H^{\prime}=3.271, \mathrm{D}=0.947$ of 67 species, it means $40.54 \%$ of all species in all sites. The lowest diversity was on sandy beaches, Trianggulasi and Bedul. The diversity is very high in the place where Gastropod can hide and more sources as food. The taxa distribution tone of rocky beaches and muddy beaches are similar to sandy beaches. Neogastropods are distributed from the upper to lower subzones. Therefore, the distribution of gastropods in APNP well described by corresponding analysis, and mostly is a type B distribution pattern. This information could be useful for sustainable management of coastal biodiversity.

\section{ACKNOWLEDGEMENTS}

This research was funded and supported by KEMENRISTEK-DIKTI: DRPM-PDD 2018. Many thanks
Universitas 17 Agustus 1945 Banyuwangi; Faculty of Biology, Universitas Gadjah Mada (UGM), Yogyakarta; Alas Purwo National Park; Prof. Hans Lamal and Elise Pressley for engaging discussions and helpful advice, Yves Samyn, the curator of the Museum of Natural Sciences in Brussels, Belgium, for his assistance in species identification; Laboratory of Biology of Universitas 17 Agustus 1945 Banyuwangi; Laboratory of Ecology, Faculty of Biology, UGM, Yogyakarta; and my team.

\section{REFERENCES}

Abraham JP, Baringer M, Bindoff NL, Boyer T, Cheng LJ, Church JA, Conroy JL, Domingues CM., Fasullo JT, Gilson J, Goni G, Good SA, Gorman JM, Gouretski V, Ishii M, Johnson GC, Kizu S, Lyman JM, Macdonald AM, Minkowycz WJ, Moffitt SE, Palmer MD, Piola AR, Reseghetti F, Schuckmann K, Trenberth KE, Velicogna I, Willis JK. 2013. A review of global ocean temperature observations: Implications for ocean heat content estimates and climate change. Rev Geophys 51: 450-483

Adrain JM, Westrop SR, Chatterton DE. 2000. Silurian trilobite alpha diversity and the end-Ordovician mass extinction. Paleobiology 26: 625-646.

Alavi-Yeganeh MS, Beirami N, Bahmani G, Seyfabadi J. 2016. Size-mass relationships for four marine nerite snails (Gastropoda: Neritidae) from the northern coast of Persian Gulf, Iran. Zool Ecol 26 (4): 292294.

Alongi DM 2009. The Energetics of Mangrove Forest. Springer, Australia.

Alvaro A. 2007. Littoraria scabra, on mangrove trees Nananu-ira Fiji Island. Mar Freshwater Behav and Phy 40 (4): 247-255.

Arau jo CVM, Moreira-Santos M, Patrı'cio J, Martins I, Moreno-Garrido I, 'n Blasco J, Marques JC, Ribeiro R. 2015. Feeding niche preference of the mudsnail Peringia ulvae. Mar Freshw Res 66: 573-581. DOI: 10.1071/MF14021

Azeda C, Erica Sá, Silva G, Medeiros JP, Tavares MJ, de Almeida PR, Metelo I, Costa JL, Costa MJ. 2013. Preliminary results of biological monitoring using benthic macroinfauna of the discharge areas of Lisbon drainage basins in Tagus estuary after new developments in sanitation infrastructures. J Sea Res 83: 163-172.

Baeta A, Niquil N, Marques JC, Patri'cio J. 2011. Modelling the effects of eutrophication, mitigation measures and an extreme flood event on estuarine benthic food webs. Ecol Model 222: 1209-1221. DOI: 10.1016/J.ECOLMODEL.2010.12.010

Brazeiro A. 2001. Relationship between species richness and morphodynamics in sandy beaches: what are the underlying factors? Mar Ecol Prog Ser 224: 35-44.

Braga-Henriques A, Carreiro-Silva M, Porteiro FM, de Matos V, Sampaio I, Ocana O, Avila SP. 2011 The association between a deep-sea gastropod Pedicularia sicula (Caenogastropoda: Pediculariidae) and its coral host Errina dabneyi (Hydrozoa: Stylasteridae) in the Azores. J Mar Sci 68 (2): 399-407

Brewer R. 1993. The Science of Ecology. Second Edition. Saunders College Pub., Tokyo.

Chapperon C, Seuront L. 2011. Variability in motion behaviour of intertidal gastropods: Ecological and evolutionary perspectives. J Mar Biol Assoc UK 91 (1): 237-244.

Chappuis E, Terradas M, Cefalì ME, Mariani S, Ballesteros E. 2014. Vertical zonation is the main distribution pattern of littoral assemblages on rocky shores at a regional scale. Estuar Coast Shelf Sci 147: 113-122

Dance SP. 1992. Shells. The Visual Guide to over 500 Species of Seashell from Around the World. Dorling Kindersley Book. London. 256 p.

De Lucena JM, de Meirelles, CAO, Matthews-Cascon H. 2012. Feeding behavior of Nassarius vibex (Gastropoda: Nassariidae). Arquivos de Ciências do Mar Fortaleza 45 (2): 60-67.

Defeo O, McLachlan A, Schoeman DS, Schlacher T, Dugan J, Jones A, Lastra M, Scapini F. 2008. Threats to sandy beach ecosystems: A review. Estuar Coast Shelf Sci. DOI: 10.1016/j.ecss.2008.09.022.

Degraer S, Verfaillie E, Willems W, Adriaens E, Vinx M, Van Lanker V. 2007. Habitat suitability modellings as mapping tool for macrobenthic 
communities: an example from the Belgian part of the North Sea. Cont Shelf Res. DOI: 10.1016/JSR/2007.09.001.

Dharma B. 2005. Recent and Fossil Indonesian Shells. Conch Book. Germany.

Dorgan KM, Jumars PA, Johnson BD, Boudreau BP. 2006. Macrofaunal burrowing: The medium is the message. Oceanogr Mar Biol Ann Rev 44: 85-121.

Eichhorst TE. 2016. Neritidae of the World. Vol. 1. Conch Books, Harxheim, Germany.

Fong JM, Lai S, Yaakub SM, Ow YX, Todd P. 2018. The diet and feeding rates of gastropod grazers in Singapore's seagrass meadows. Bot Mar 61 (3): 181-192. DOI: 10./515/bot-2017-0091.

Gladstone W, Loisier A, Herbert C. 2007. Central Coast Rocky Shore Biodiversity Assessment. [Final Report-Project Cae 06017]. The University of Newcastle, Australia.

Hammer Ø, Harper DAT, Ryan PD. 2001. Past: Paleontological statistics software package for education and data analysis. Palaeontol Electron 4 (1): 1-9.

Harley CD, Denny MW, Mach KJ, Miller LP. 2009. Thermal stress and morphological adaptations in limpets. Funct Ecol 23 (2): 292-301.

Harper DAT. 1999. Numerical Palaeobiology. John Wiley \& Sons. New York.

Hay ME. 1997. Calcified seaweed on coral reefs: Complex defenses, trophic relationships and value as habitat.; Proceeding $8^{\text {th }}$ International Coral Symposium 1: 713-718.

Hennebert M, Lees A. 1991. Environmental gradients in carbonate sediments and rocks detected by correspondence analysis: examples from the recent of Norway and the dinantian of southwest England. Sedimentology 38: 623-642.

Hoeksema BW, Gittenberger A. 2008. Records of some marine parasitic molluscs from Nha Trang, Vietnam. Basteria. 72: 129-133.

Hoffman L, Fraussen K, Freiwald A. 2018. The genus Chauvetia (Gastropoda, Buccinoidea) in deep-water coral habitats on the continental slope of Mauritania. Misc Malacol 7 (6): 127-138.

Holzer KK, Rueda JL, McGlathery KJ. 2011a. Caribbean seagrass as a food source for the emerald neritid Smaragdia viridis. Am Malacol Bull 29: 63-67.

Holzer KK, Rueda JL, McGlathery KJ. 2011b. Differences in the feeding ecology of two seagrass-associated snails. Estuar Coasts 34: 11401149. DOI: $10.1007 / \mathrm{s} 12237-011-9406-6$

Irma D, Sofyatuddin K. 2012. Diversity of gastropods and bivalves in mangrove ecosystem rehabilitation areas in Aceh Besar and Banda Aceh Districts, Indonesia. Aquac Aquar Conserv Legis 5 (2): 55-59.

Jones AR, Schacher TA, Schoeman DS, Dugan JE, Defeo O, Scapini F, Lastra M, Mclachlan A. 2009. Sandy-beach ecosystem: their health, resilience and management. Proceeding Fifth International Symposium on Sandy Beaches. Rabat Morocco, 19-23 October 2009.

Kantor YI, Puillandre N, Fraussen K, Fedosov AE. Bouchet P. 2013 Deep-water Buccinidae (Gastropoda: Neogastropoda) from Sunken wood, vents and seeps: Molecular phylogeny and taxonomy. J Mar Biol Assoc UK 93 (8): 2177-2195. DOI 10.1017/S0025315413000672

Kawaroe M, Nugraha AH, Juraij1, Tasabaramo IA. 2016. Seagrass biodiversity at three marine ecoregions of Indonesia: Sunda Shelf Sulawesi Sea, and Banda Sea. Biodiversitas 17 (2): 585-591. DOI: 10.13057/biodiv/d170228

Koperski P. 2010. Diversity of macrobenthos in lowland streams: ecological determinants and taxonomic specificity. J Limnol 69 (1): 88-101. DOI: $10.3274 / J L 10-69-1-08$.

Krebs CJ. 1989. Ecological Methodology. Harper \& Row, New York.

Krebs CJ. 1999. Ecological Methodology. 2nd ed. Benjamin Cummings Publisher. Menlo Park, CA

Kroeker KJ, Kordas RL, Crim R, Hendriks IE, Ramajo L, Singh GS, Duarte CM, Gattuso JP. 2013 Impacts of ocean acidification on marine organisms: Quantifying sensitivities and interaction with warming. Glob Chang Biol 19 (6): 1884-1896.

Leite FPP, Tambourgi MRS, Cuncha CM. 2009. Gastropods associated with the green seaweed Caulerpa racemosa, on two beaches of the Northern coast of the State of São Paulo, Brazil. Strombus 16: 1-10.

Llovel W, Terray L. 2016. Observed southern upper-ocean warming over 2005-2014 and associated mechanisms. Environ Res Lett 11: 1-13.

Marques L, Carric A, Bessa F, Gaspar R, Neto JM, Patrício J. 2013. Response of intertidal macrobenthic communities and primary producers to mitigation measures in a temperate estuary. Ecol Indic 25: $10-22$.
Marshall FE, Banks K. 2013. Shoreline Habitat: Beaches. Marine and Estuarine Goal Setting for South Florida [Report]: 94-108. www.sofla-mares.org

Morisita M. 1962. Id-Index, a measure of dispersion of individuals. Res Popul Ecol 4 (1): 1-7.

Moreira J, Aldea C, Troncoso JS. 2010. Temporal dynamics of gastropod fauna on subtidal sandy sediments of the Ensenada de Baiona (NW Iberian Peninsula). Helgoland Mar Res 64 (4): 311-320. DOI: 10.1007/s10152-009-0186-3

Mujiono N. 2009. Mudwhelks (Gastropoda: Potamididae) from Mangroves of Ujung Kulon National Park, Banten. Jurnal Biologi 13 (2): 51-56. [Indonesian]

Nekhaev IO. 2011. Two species of parasitic molluscs new for Russian seas. Ruthenica 21 (1): 69-72.

Nguyen KD, Morley SA, Lai CH, Clark MS, Tan KS, Bates AE, Peck LS. 2012. Upper temperature limits of tropical marine ectotherms: Global warming implications. PLoS ONE 6 (12): e29340. DOI: 10.1371/journal.pone.0029340.

Niamaimandia N, Javadzadeh N, Kabgani N, Vaghei RG, Rajabzadeh I. 2017. Biodiversity of the gastropods in different periods in intertidal zone of the Iranian waters of the Persian Gulf. Reg Stud Mar Sci 13: 59-63.

Nontji A. 2007. Laut Nusantara. Penerbit Djambatan. Jakarta. [Indonesian]

Nybakken JW. 1992. Biologi Laut, Suatu Pendekatan Ekologis. Translated by: Eidman M, Bengen DG, Koesoebiono, Hutomo M, Sukristijono. PT Gramedia. Jakarta. [Indonesian]

O’Dwyer K, Kamiya T, Poulin R. 2014. Altered microhabitat use and movement of littorinid gastropods: The effects of parasites. Mar Biol 161: 437-445.

Parker LM, Ross PM, Connor WAO, Portner HO, Scanes E, Wright JM. 2013. Predicting the response of molluscs to the impact of ocean acidification. Biology 2: 651-692.

Peharda M, Morton B. 2005. Experimental prey species preference of Hexaplex trunculus (Gastropoda: Muricidae) and predator-prey interactions with the Black Mussle Mytilus galloprovincialis (Bivalvia: Mytilidae). Mar Biol 148 (5): 1011-1019.

Pfaff MC, Nel R. 2019. Intertidal Zonation. Reference Modul in Earth System and Environmental Sciences. Second edition. Vol 1: 97-107. Elsevier. DOI: 10.1016/B978-0-12-409548-9.11184-4

Poutiers JM. 1998. Gastropods. In: Carpenter KE, Niem VH. (eds.) FAO Species Identification Guide for Fishery Purposes. The Living Marine Resources of the Western Central Pacific. Volume 1. Seaweeds, Corals, Bivalves and Gastropods. Food and Agriculture Organization, Rome.

Raffo MP, Russo VL, Schwindt E. 2014. Introduced and native species on rocky shore macroalgal assemblages: Zonation patterns, composition and diversity. Aquat Bot 112: 57- 65 .

Rahmayanti F, Nazira FK, Dewi AK, Oktaviani DF, Millaty INK, Prasetya TA, Sasmita HB, Nashrurrokhman M, Roshitafandi DA, Febiansi D, Sartika HW, Zulfikar WG, Kurnia RN, Islami DA, Tranggono YA. 2018. Biodiversity of gastropod in the Sombu Beach, Wakatobi, Indonesia. The 2nd International Symposium on Marine and Fisheries Research. IOP Conf Ser Earth Environ Sci 139 (2018): 012013. DOI: $10.1088 / 1755-1315 / 139 / 1 / 012013$

Requia WJ. 2018. Modelling spatial distribution of population for environmental epidemiological studies: Comparing the exposures estimates using choropleth versus desimetric mapping. Environ Intl 119: $152-164$

Rodríguez-Revelo N, Espejel I, García CA, Ojeda-Revah L, María Alejandra Sánchez Vázquez MAS. 2018. Environmental Services of Beaches and Coastal Sand Dunes as a Tool for Their Conservation. Botero CM et al. (eds.), Beach Management Tools - Concepts, Methodologies and Case Studies, Coastal Research Library 24. Springer, Berlin. DOI: 10.1007/978-3-319-58304-4_5.

Rossini REA, Rueda JL, Tibbetts AIR. 2014. Feeding ecology of the seagrass-grazing nerite Smaragdia souverbiana (Montrouzier, 1863) in subtropical seagrass beds of Eastern Australia. J Molluscan Stud 80: 139-147. DOI: $10.1093 /$ mollus/eyu003

Rumahlatu D, Leiwakabessy F. 2017. Biodiversity of gastropoda in the coastal waters of Ambon Island, Indonesia. Aquac Aquar Conserv Legis 10 (2): 285-296

Schlacher TA, Schoeman DS, Jones AR, Dugan JE, Hubbard DM, Defeo O, Peterson CH, Weston MA, Maslo B, Olds AD, Scapini F, Nel R, Harris LR, Lucrezi S, Lastra M, Huijbers CM, Connolly RM. 2014. 
Metrics to assess ecological condition, change, and impacts in sandy beach ecosystems. J Environ Manag 144: 322-335.

Scrosati RA, Knox AS, Valdivia N, Molis M. 2011. Species richness and diversity across rocky intertidal elevation gradients in Helgoland: Testing predictions from an environmental stress model. Helgol Mar Res 65: 91-102. DOI: 10.1007/s10152-010-0205-4

Short AD. 2012. Coastal processes and beaches. Nat Educ Knowledge 3 (10): 15 .

Smith-Gill SJ. 1975. Cytophysiological basis of disruptive pigmentary pattern in leopard frog Rana pipiens. II wild type and mutant cellspecific pattern. J Morphol 146: 35-54.

Strong EE, Gargominy O, Ponder WF, Bouchet P. 2008. Global diversity of gastropods (Gastropoda; Mollusca) in freshwater. Hydrobiologia 95: $149-166$

Suratissa DM, Rathnayake U. 2017. Effect of pollution on diversity of marine gastropods and its role in trophic structure at Nasese Shore, Suva, Fiji Islands. J Asia-Pacific Biodivers 10: 192-198.

Susintowati, Hadisusanto S. 2014. Bioaccumulation of mercury and the hepatopancreas structure of Terebralia sulcata and Nerita argus (Mollusca: Gastropoda) in Ceased Lampon Gold Mining, Banyuwangi District, East Java. Manusia dan Lingkungan 21 (1): 34 40. [Indonesian]

Swennen C (Kees). 2011. Large mangrove-dwelling Elysia species in Asia, with descriptions of two new species (Gastropoda: Opisthobranchia: Sacoglossa). Raffles Bull Zool 59 (1): 29-37.

Takano T, Hirano YM, Trowbridge CD, Hirano YJ, Watano Y. 2013. Taxonomic clarification in the genus Elysia (Gastropoda: Sacoglossa): E. Atroviridis and E. Setoensis. Am Malacol Bull 31 (1): 25-37.

Tan KS. 2008. Mudflat predation of bivalves and gastropods by Chicoreus capucinus (Neogastropoda: Muricidae) at Kungkrabraen Bay, Gulf of Thailand. Raffles Bull Zool 18: 235-245.
Thatje S, Brown A. 2009. The macrobenthic ecology the straits of Magellan and the Beagle Channel. Ann Ins Patagonia 37 (2): 17-27.

Tongco MDC. 2007. Purposive sampling as a tool for informant selection. Ethnobotany Research \& Application. J Plants People Appl Res 5: 147-158.

Tothmeresz B. 1995. Comparison of different methods for diversity ordering. J Vegetation Sci 6: 283-290.

Unabia CRC. 2011. The snail Smaragdia bryanae (Neritopsina, Neritidae) is a specialist herbivore of the seagrass Halophila hawaiiana (Alismatidae, Hydrocharitaceae). Invertebr Biol 130 (2): 100-114.

Van der Linden P, Marchinib A, Dolbethc M, Patrícioe J, Veríssimoa H, Marques JC. 2016. The performance of trait-based indices in an estuarine environment. Ecol Indic 61: 378-389.

Vanagt T, Vincx M, Degraer S. 2008. Is the burrowing performance of a sandy beach surfing gastropod limiting for its macroscale distribution? Mar Biol 155(4): 387-397. DOI: 10.1007/s00227-0081035-7.

Vermeij GJ. 2017. Shell features associated with the sand-burying habit in gastropods. J Molluscan Stud 83: 153-160. DOI: 10.1093/mollus/eyx001.

Wittmann AC, Pörtner HO. 2013. Sensitivities of extant animal taxa to ocean acidification. Nat Clim Change 3 (11): 995-1001.

Yang Y, Chui TFM, Shen PP, Yang Y, Gu JD. 2018. Modelling the temporal dynamics of intertidal benthic infauna biomass with environmental factors: impact assessment of land reclamation. Sci Total Environ 618: 439-450.

Yolanda R, Asiah, Dharma B. 2016. Mudwhelks (Gastropoda: Potamididae) in mangrove forest of Dedap, Padang Island, Kepulauan Meranti District, Riau Province, Indonesia. J Entomol Zool Stud 4 (2): $155-161$ 